\title{
IMPACT OF ALGINATE TYPE AND BEAD DIAMETER ON MASS TRANSFERS AND THE METABOLIC ACTIVITIES OF ENCAPSULATED C3A CELLS IN BIOARTIFICIAL LIVER APPLICATIONS
}

\author{
A. Gautier, B. Carpentier, M. Dufresne, Q. Vu Dinh, P. Paullier and C. Legallais* \\ University of Technology of Compiègne, UMR CNRS 6600, Laboratory of Biomechanics and Bioengineering, \\ Royallieu Research Center, B.P. 20529, Compiègne, France
}

\begin{abstract}
Liver-assist devices have been developed in the last few decades to support patients with liver failure on the road to recovery or transplantation. Fluidised bed bio-artificial livers - where liver cells are encapsulated within alginate beads - appear to be a valuable alternative to hollow fibre devices for improving mass transfers and enhancing treatment efficacy. This approach nevertheless deserves optimization in terms of bead production. The aim of this study was to investigate the impact of alginate type and of two bead diameters $(1000 \mu \mathrm{m}$ and $600 \mu \mathrm{m})$ on mass transfers within beads and on the biological functions of encapsulated $\mathrm{C} 3 \mathrm{~A}$ cells.

After assessing the effect of the encapsulation process on bead quality, we investigated cell viability and metabolic activities (ammonia, albumin, $\alpha$-foetoprotein synthesis and glucose consumption). They were successfully maintained over $48 \mathrm{~h}$ within fluidised bed bioreactors, independently of alginate type and bead diameter. Mass transfers were not significantly influenced by the latter parameters. Finally, suggestions are made for improving the entrapment process as a means of enhancing the treatment efficiency of the fluidised bed bioartificial liver.
\end{abstract}

Keywords: Alginate, encapsulation, hepatocyte, tissue engineering, liver.

*Address for correspondence:

C. Legallais

Laboratory of Biomechanics and Bioengineering

University of Technology of Compiègne, UMR CNRS 6600

Royallieu Research Center

B.P. 20529

F-60205 Compiègne, France

Telephone Number: +33 (0)344234401

Fax Number: +33 (0)3 44237942

E-mail: cecile.legallais@utc.fr
Introduction

As the liver has various, fundamental metabolic activities, it is a central and vital organ. It participates in nutrient absorption, storage and delivery according to the body's demands and plays a key role in the biotransformation, detoxification and elimination of endogenous wastes (such as ammonia or bilirubin), medicines and exogenous toxins. It synthesizes most of the amino acids and plasma proteins (e.g. albumin, coagulation factors), performs several roles in carbohydrate metabolism, such as gluconeogenesis, glycogenolysis and glycogenesis, and plays a key role in lipid metabolism (cholesterol synthesis or elimination, production of triglycerides) (Carpentier et al., 2009).

Acute and acute-on-chronic types of liver failure can thus result in life-threatening complications caused by decreased detoxification, storage and synthesis functions. Losses in liver functions may directly impact a patient's prognosis and short-term survival. In these cases, liver transplantation is the only efficient treatment. The European Liver Transplant Registry references more than 2000 patients on the waiting list. This number increases by $10 \%$ per year, as does the number of deaths of patients waiting for a transplant. Extracorporeal liver assist devices have therefore been developed and evaluated in the last few decades, to support and bridge critically ill patients on their road to either recovery or transplantation.

These liver-assist devices are of two types: artificial and bioartificial livers (Legallais et al., 2008). Whereas artificial livers use mechanical and chemical components only to remove toxins, bioartificial livers (BAL) combine artificial components and liver cells confined within bioreactors, ideally to restore all liver functions. For this particular application, numerous requirements must be satisfied in order to maintain, support and favour cell survival and functionality. Cells must be isolated from the external environment and immobilized within a favourable and biocompatible tri-dimensional scaffold (Jiankang et al., 2009). Among other types, the HepG2/ $\mathrm{C} 3 \mathrm{~A}$ cell line has been accepted as a model to study in vitro liver regeneration and extracorporeal liver support systems (Tsai and Lin, 2009). Cell morphology and organization must be as physiological as possible so that the cells can express most of their metabolic activities. For instance, Berthiaume et al. (1996) showed that sandwich culture resembling that found in the liver (i.e., where hepatocytes are generally bounded by extracellular matrix at each of their opposite basolateral membrane domains) resulted in the formation of a 2-dimensional (2D), multicellular network with a functional bile canalicular network and induced a dramatic increase in the expression 


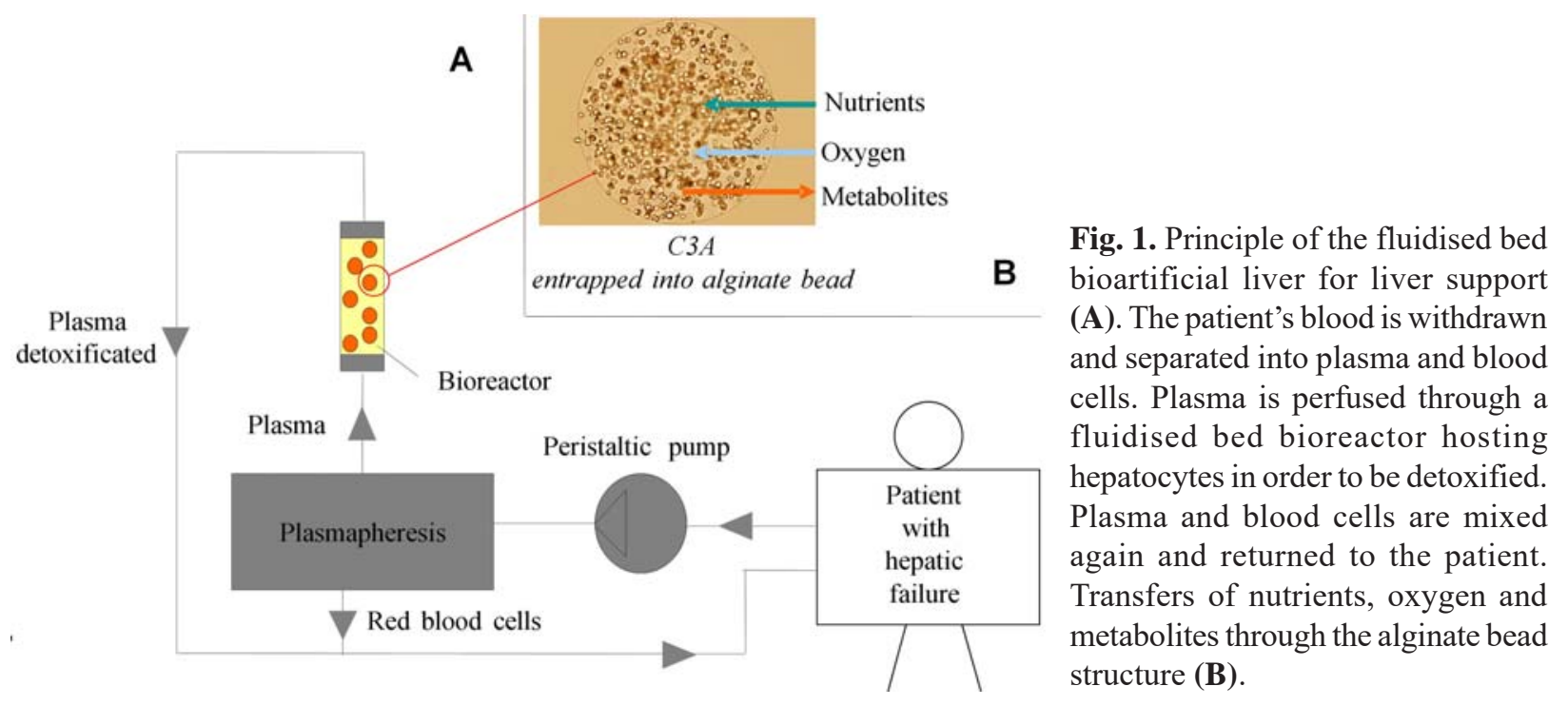

of liver-specific functions when compared to cultures on a single extracellular matrix-coated surface. Other authors confirmed the same trend, leading to prolonged cell differentiation (Tuschl et al., 2009). Vollmar and Menger (2009), in a very recent review also pointed out the role of microcirculation to guarantee hepatic homeostasis: indeed, not only is a sufficient nutritive perfusion and oxygen supply required, but also a balanced vasomotor control and appropriate cell-cell communication.

Furthermore, the porous biomaterial should act as a semi-permeable barrier between the patient's blood or plasma and the liver cells. Low molecular weight (LMW) blood solutes, such as glucose or ammonia, should be able to reach the cells to be metabolized. In the other direction, LMW solutes such as urea as well as small proteins, such as albumin (molecular weight 66,000 Da) should be able to transfer from the cell compartment to the blood side. Naturally, proper cell oxygenation is also always a prerequisite.

Different types and configurations of bioartificial livers are currently being investigated, most of them relying on semi-permeable hollow fibre modules (Legallais et al., 2001). Another option is to employ bioreactors derived from powder technology such as fluidised bed systems. These devices - where liver cells are entrapped within biocompatible spheroids such as beads or capsules provide a suitable and valuable option for improving nutrient and oxygen transfers, favouring the intake and transformation of lethal toxins, as well as the release of essential proteins from the cell-containing beads to the fluid (Fig. 1). Alginate is an unbranched natural copolymer composed of $\beta$-D-mannuronate (M) and $\alpha$-L-guluronate (G), linked together by 1,4 bonds (Garbayo et al., 2002; Bajpai and Sharma, 2004). Due to its relative stability, biocompatibility, adjustable porosity and simplicity of use, alginate is thus a biomaterial of choice when it comes to entrapping cells (Garbayo et al., 2002; Zmora et al., 2002; David et al., 2004a; De Vos et al., 2006; Zimmermann et al., 2007; Wikstrom et al., 2008), to cell therapy (Chang, 2005; Paul et al., 2009) or to being used in medical devices (Ueyama et al., 2002; Orive et al., 2004; Gao et al., 2005; De Vos et al., 2006; Orive et al., 2006; Wikstrom et al.,
2008). Some of these studies were conducted with hepatocytes that were either encapsulated within alginate beads (Selden et al., 1999; David et al., 2004b; Gao et al., 2005; Kinasiewicz et al., 2007; Kinasiewicz et al., 2008) or capsules (Canaple et al., 2001; Orive et al., 2004; Haque et al., 2005), or seeded within alginate scaffolds (Zmora et al., 2002; Seo et al., 2006). More specifically, the effects of the type of alginate on human hepatocyte cell line cultures were studied by Khalil et al. (2001). Albumin secretion increased between day 4 and day 8 and then decreased until day 15 . The difference in albumin secretion between both types of alginate (high mannuronic versus high guluronic content) was more evident in the first period (4-8 days) than after day 8. High mannuronic alginate appeared to be a preferential support for cells as far as albumin secretion was considered as a marker.

As a supplement to the first feasibility studies (David et al., 2004a; David et al., 2004b), fluidised bed BAL (FBBAL) - based on alginate beads - merited optimization to ensure high levels of solute exchange to improve their efficiency and reduce treatment duration. In FBBAL, mass transfers are both diffusive (mainly within the beads) and convective (in the bioreactor itself). Lessening bead size seemed worthwhile as a means of enhancing diffusion due to i) the reduction of diffusion distances and ii) the increase in bead surface-to-volume ratio. The hypothesis on the advantages of a lower bead diameter nevertheless needed to be investigated. In addition, we studied the impact of alginate type and density on BAL functions.

The aim of the present study was to compare overall mass transfer efficiency and functionality of encapsulated C3A cells for various types of alginate and bead diameters. The alginates used were all composed of $69 \%$ mannuronate and $31 \%$ guluronate, a ratio that favoured diffusion of vitamin B12 within the beads (Lewinska et al., 2002). Vitamin B12 is a neutral low molecular weight marker (1,355 Da), which does not adsorb on alginate gels. David et al. also showed that this alginate composition was satisfactory for safely entrapping cells in the surrounding fluid (David et al., 2006). Before carrying out the biological studies, it was necessary to optimize the encapsulation process so as to produce well-formed alginate beads. Mass 
Table 1. Biochemical constitution of investigated alginate solutions.

\begin{tabular}{|c|c|c|c|c|}
\hline $\begin{array}{c}\text { Type of alginate } \\
\text { (cps, at 2\% in water and 25 }{ }^{\circ} \mathbf{C} \text { ) }\end{array}$ & M/G ratio & $\begin{array}{c}\text { Chain length } \\
\text { (Dalton) }\end{array}$ & $\begin{array}{c}\text { Concentration } \\
\text { (w/v ratio) }\end{array}$ \\
\hline $\begin{array}{c}\text { Low viscosity alginate 1\% } \\
\text { (LV 1\%) }\end{array}$ & 257 & $69 / 31$ & $\begin{array}{c}12,000 \\
\text { to } 80,000\end{array}$ & $1 \%$ \\
\hline $\begin{array}{c}\text { Low viscosity alginate 2\% } \\
\text { (LV 2\%) }\end{array}$ & 257 & $69 / 31$ & $\begin{array}{c}12,000 \\
\text { to } 80,000\end{array}$ & $2 \%$ \\
\hline $\begin{array}{c}\text { Low viscosity alginate 2.2\% } \\
\text { (LV 2.2\%) }\end{array}$ & 257 & $69 / 31$ & $\begin{array}{c}12,000 \\
\text { to } 80,000\end{array}$ & $2.2 \%$ \\
$\begin{array}{c}\text { Medium viscosity alginate } \\
1.5 \% \text { (MV 1.5\%) }\end{array}$ & 3960 & $69 / 31$ & $\begin{array}{c}8000 \\
\text { to } 120,000\end{array}$ & $1.5 \%$ \\
\hline
\end{tabular}

transfer efficacy was first determined using procedures similar to those of Lewinska et al. (2002).

For future bio-artificial liver applications, the feasibility of culturing liver cells (C3A cell line) within several types of alginate beads during an extended $48 \mathrm{~h}$ period of time was also investigated for proof of adaptability to the threedimensional environment. Morphology, viability and the metabolic activities of the liver cells were assessed throughout culture.

\section{Materials and Methods}

\section{Alginate bead production and C3A microencapsulation \\ Biochemical composition of alginate solutions}

Two types of alginate from Macrocystis pyrifera (brown algae) were used: low viscosity (A0682, Sigma-Aldrich, St. Louis, MO, USA) and medium viscosity (A2033, Sigma-Aldrich). Their composition depends on both the mean molecular weight of the $\mathrm{M}$ and $\mathrm{G}$ monomers and alginate concentration. Low viscosity (LV) alginate solution was composed of monomeric chains whose molecular weight ranged from 12,000 to $80,000 \mathrm{Da}$, whereas medium viscosity (MV) alginate solution contained 80,000 to 120,000 Da chains. Table 1 summarizes the biochemical composition of the alginate solutions evaluated in this study. To prepare these solutions, the alginate powder was dissolved in a sterile saline solution (154 mM NaCl solution buffered with $10 \mathrm{mM}$ Hepes, $\mathrm{pH}$ 7.4). The mixture was then filtered using a 0.2 $\mu \mathrm{m}$ membrane.

\section{Preparation of cell-containing alginate suspensions Cell subculture}

C3A human hepatocellular carcinoma cells, provided by the American Type Culture Collection (ATCC, reference CRL 10-741, LGC Standards Sarl, Molsheim, France or http://www.lgcstandards-atcc.org/) were used to complete the study. Before encapsulation, $\mathrm{C} 3 \mathrm{~A}$ cells were cultivated in a $37^{\circ} \mathrm{C}$ and $5 \% \mathrm{CO}_{2}$ incubator in standard $\mathrm{T} 75$ Falcon culture flasks (Merck Eurolab, Strasbourg, France), in 15 $\mathrm{ml}$ of complete culture medium: Minimum Essential Medium Earle's salts (MEM) with glucose $1 \mathrm{~g} / 1$ supplemented with $0.2 \%$ L-glutamine $(200 \mathrm{mM}), 0.5 \%$ penicillin-streptomycin (10,000 units/ml and 10,000 $\mu \mathrm{g} /$ $\mathrm{ml}$, respectively), $1 \%$ non essential amino acids (10 $\mathrm{mM})$, $1 \%$ Hepes buffer solution $(1 \mathrm{M}), 1 \%$ sodium pyruvate $(100$ $\mathrm{mM}$ ) and $10 \%$ foetal calf serum, from Gibco (Cergy
Pontoise, France). Cells were seeded at 40,000 cells $/ \mathrm{cm}^{2}$, and after a 7-day incubation period, $80-90 \%$ confluence was obtained, corresponding to 25 to $30 \times 10^{6}$ cells. The cells were used from passage number 5 to number 30 .

\section{Suspension of cells in alginate solution}

C3A-containing alginate solutions were prepared in a sterile environment. The cells were dissociated by incubation with trypsin-EDTA $0.25 \%$ for 10 to $15 \mathrm{~min}$ at $37^{\circ} \mathrm{C}$. This step was carefully followed to obtain a homogeneous cell suspension of single entities or 2-5 cell aggregates. After trypsinisation $50 \times 10^{6} \mathrm{C} 3 \mathrm{~A}$ cells were isolated and mixed with either $2.2 \% \mathrm{w} / \mathrm{v}$ low viscosity or $1.5 \% \mathrm{w} / \mathrm{v}$ medium viscosity alginate powder dissolved in a final volume of $10 \mathrm{ml}$ of sterile saline solution. Cell density in the suspension was $5 \times 10^{6}$ cells per $\mathrm{ml}$ of alginate solution.

\section{Alginate solution extrusion}

Alginate beads were produced by means of an extrusion method using a homemade system (Fig. 2). $10 \mathrm{ml}$ of a cell-free or cell-containing alginate solution (cell suspension) were extruded at a flow rate of $5.65 \mathrm{ml} / \mathrm{min}$ through the lumen of a needle using a roller pump (Ismatec IPC Type ISM934 VA.01, Glattbrugg, Switzerland). Overall, the extrusion stage lasted 6 min. Droplet diameter was controlled by applying a coaxial air-flow preliminary filtered with $0.2 \mu \mathrm{m}$ filter. A mounting piece was specially designed to guide the air-flow along the needle axis. Air flow intensity was adjusted using a flow meter (Sho-rate Emerson Electric; Brooks, Hatfield, PA, USA). Once formed, the alginate droplets were collected in a calcium chloride gelation bath (154 mM NaCl, $10 \mathrm{mM}$ Hepes, 115 $\mathrm{mM} \mathrm{CaCl}$ ) wherein they were immerged and reticulated for $15 \mathrm{~min}$. Afterwards, the beads were rinsed twice with sterile saline solution. The cell-free beads were then stored in the same solution before use, whereas the cell-containing beads were submitted to an additional step of rinsing with $70 \mathrm{ml}$ of culture medium and finally placed in a culture vessel in which $15 \mathrm{ml}$ of culture medium was added for transitory storage before the fluidisation experiment. All steps were carried out in sterile conditions for $\mathrm{C} 3 \mathrm{~A}$ encapsulation.

\section{Bead diameter measurement}

Bead diameter was quantified by geometrical measurements on an inverted light microscope equiped with phase contrast (Leica DMI 6000B, LAS AF software; Leica, Wetzlar, Germany). For each experiment, the 


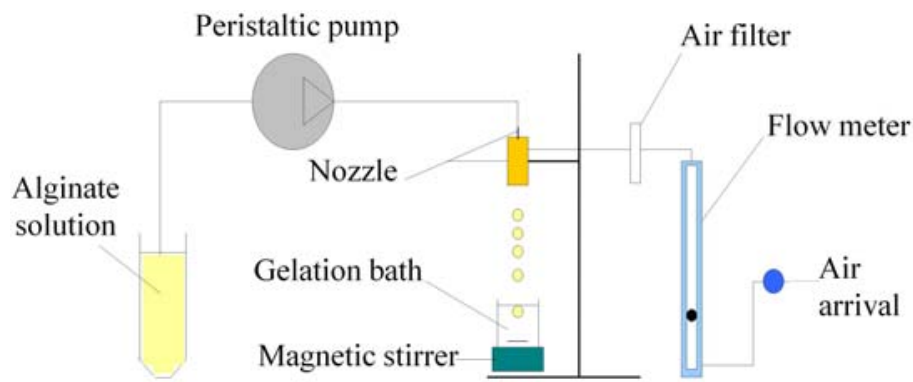

Fig. 2. Scheme of the encapsulation setup. The air-flow can be adjusted to control droplet diameter during extrusion. diameter of 30 alginate beads was measured orthogonally in order to check their sphericity. Averages and standard deviations were then calculated.

\section{Dynamic culture of encapsulated C3A cells \\ Fluidised bed bioreactor}

A macro-scale bioreactor was designed in our laboratory using Solid Works software (SolidWorks Europe, Vélizy, France). It was subsequently manufactured by Medicolab (Templemars, France), in glass so as to be autoclavable. The bioreactor is composed of a hollow column made of glass (internal diameter $1.35 \mathrm{~cm}$; height $17 \mathrm{~cm}$ ) sealed with two water-tight perforated caps top and bottom through which penetrate the inlet and outlet channels respectively. The concept of fluidised bed has been detailed thoroughly in a previous work (Doré and Legallais, 1999; Legallais et al., 2000). Briefly, this type of perfusion led to a permanent motion of the beads in a defined volume, and promoted interactions and exchanges between solid and liquid phases. A stable bed expansion with homogenous mixing could be obtained applying adequate hydrodynamic conditions.

\section{Dynamic cell culture}

Dynamic perfusion of the encapsulated cells was performed inside a closed-loop circuit incorporating the above-described bioreactor (Fig. 3A). The fluidised bed bioreactor was connected to a perfusion loop by means of silicone tubing ( $1.3 \mathrm{~mm}$ internal diameter). Following cell encapsulation, cell-housing alginate beads were placed inside the bioreactor via the upper port. The final volume of culture medium in the circuit was $42 \mathrm{ml}$. Cell-containing alginate beads were fluidised at 6 and $10 \mathrm{ml} / \mathrm{min}$ for 600 and $1000 \mu \mathrm{m}$ beads respectively. These flow rates allowed the generation of adequate perfusion conditions for the greatest bed expansion within the bioreactor. Lift force, inducing bead motion, depends on the bead diameter (Legallais et al., 2008) and can be adjusted through changes in perfusion flow rates. Under these conditions, mass transfers are also optimized. The whole circuit except the pump was placed in an incubator at $37^{\circ} \mathrm{C}$ and $5 \% \mathrm{CO}_{2}$ and operated continuously for up to $48 \mathrm{~h}$.

\section{Mass transfer study within cell-free beads}

Vitamin B12 was used as a middle molecular weight marker (1,355 Da) to assess mass transfer phenomena within alginate beads devoid of cells. Mass transfer experiments were carried out either in static conditions within a spectrophotometric cell (Fig. 3B) or in dynamic conditions within a fluidised bed bioreactor (Fig. 3A). All the experiments were completed using vitamin B12containing saline solutions $(154 \mathrm{mM} \mathrm{NaCl}, 100 \mathrm{mg} / \mathrm{l}$ vitamin B12). Measurements were made in triplicate using a spectrophotometer at $360 \mathrm{~nm}$.

\section{Static conditions}

A packed bed of beads $-7 \mathrm{~mm}$ high - settled at the bottom of the spectrophotometric cell (Fig. 3B). Packed bed porosity - the ratio between the liquid content of the bed of beads and its volume - was determined experimentally. Liquid content was thus estimated to be close to $40 \%$. The $\mathrm{NaCl}$ solution was wholly removed immediately before the transfer experiment and replaced by $2.4 \mathrm{ml}$ of vitamin B12 solution. Vitamin B12 absorbance was monitored for $6 \mathrm{~h}$. Measurements were carried out every $10 \mathrm{~min}$ for the first hour and every 30 min until equilibrium was reached.

\section{Dynamic conditions}

Beads obtained from the extrusion of a $10 \mathrm{ml}$ alginate solution were placed within the bioreactor column. The vitamin B12 solution was perfused through the column at the same flow rates as those used for the dynamic cell culture: $6 \mathrm{ml} / \mathrm{min}$ and $10 \mathrm{ml} / \mathrm{min}$, for 600 and $1000 \mu \mathrm{m}$ bead diameter, respectively. The bioreactor was connected to a perfusion loop by means of silicone tubing $(1.3 \mathrm{~mm}$ internal diameter). The circuit was composed of the bioreactor column, a peristaltic pump, a quartz spectrophotometric circulation cell and a chamber making satellite (shapeless alginate fragments) entrapment possible (Fig. 3A). The overall supernatant volume was $26 \mathrm{ml}$. Vitamin B12 absorbance was measured every $30 \mathrm{~s}$ for the first $10 \mathrm{~min}$ and every minute for the last $20 \mathrm{~min}$.

\section{Model for mass transfer}

The model used to determine the mass transfer coefficient $\mathrm{K}$ has been fully described in a previous work (David et al., 2004a). Several hypotheses have been proposed for the model to be successfully solved: no adsorption of vitamin $\mathrm{B} 12$ on the alginate or the inner surfaces; vitamin B12 homogenously distributed within the fluid $\left(\mathrm{C}_{\mathrm{f}}\right)$ and bead accessible volume $\left(\mathrm{C}_{\mathrm{b}}\right)$; pure diffusive transfers described by Fick's law. These hypotheses lead to eqn. (1):

$$
\frac{d\left(V_{f} C_{f}\right)}{d t}=-\frac{d\left(V_{a} C_{b}\right)}{d t}=-K A\left(C_{f}-C_{b}\right)
$$

with: $\mathrm{K}$, mass transfer coefficient

A, exchange surface of beads

$\mathrm{V}_{\mathrm{f}}$, volume of fluid

$\mathrm{V}_{\mathrm{a}}$, accessible volume in the bead 


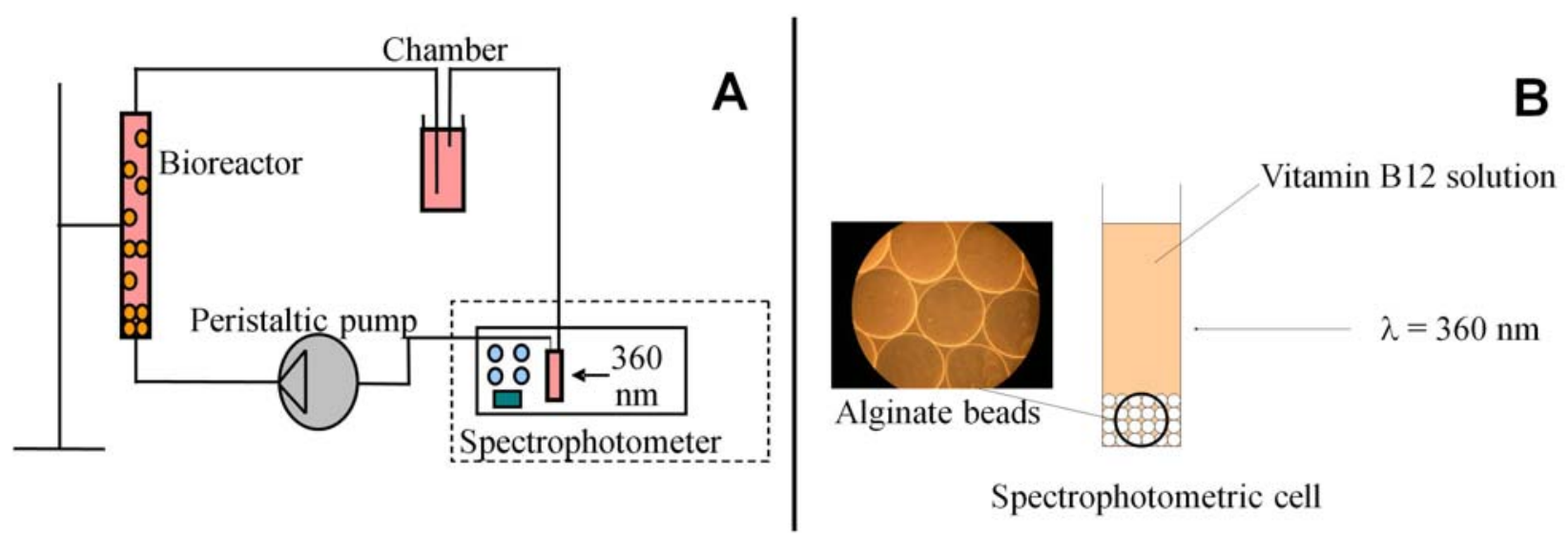

Fig. 3. (A) Experimental setup for dynamic assessment of mass transfer or dynamic culture of C3A cells within the fluidised bed bioreactor. The part limited by the dotted frame is only necessary for mass transfer experiments without cells. When dynamic culture is conducted, the whole set up except the pump is placed inside an incubator at $37^{\circ} \mathrm{C}$ and $5 \% \mathrm{CO}_{2}$. (B) Setup for mass transfer assessment in static conditions. Beads are settled at the bottom of a spectrophotometric chamber. The optical density is measured at $360 \mathrm{~nm}$. The beam crosses the chamber above bead level.

\section{Cell viability and functionality assessment \\ Viability assay}

On static culture, cell counting was performed using Mallassez's chambers, and cell viability assessed using the Trypan Blue (solution at $0.4 \%$ ) exclusion test. Immediately after encapsulation and following fluidisation, cell viability inside the beads was determined directly by means of fluorescence microscopy (Leica DMI 6000B). Orange acridine (excitation 480/40 and emission 527/30) and propidium iodide (excitation 560/40, emission 645/75) fluorescent dyes were used to label viable and dead cells, respectively. These dyes were able to penetrate the bead's structure, making it possible to visualise live cells (in green: orange acridine) and dead cells (in red: propidium iodide).

\section{Biochemical assays}

The biochemical assays were performed on samples taken from the supernatant.

Ammonia and glucose concentrations were determined with a biochemistry analyzer (Konelab 20; Thermo, CergyPontoise, France) using kits from Randox (Mauguio, France) and Thermo, respectively.

Albumin content was assessed by means of a sandwich ELISA method. Goat anti-human albumin IgG antibodies were purchased from Cappel (MP Biomedicals, Solon, $\mathrm{OH}$, USA).

Alpha-foetoprotein (AFP) levels were evaluated using a biochemistry automatus (Modular Analytics E170, Roche, Meylan, France) plus a kit from Roche (Meylan, France). Briefly, AFP was immobilized on streptavidincoated microparticles after sandwich labelling with biotin and with monoclonal anti-AFP antibody stained with ruthenium. The microparticles are retained at the electrode level by magnetic effect. Then, ruthenium is excited to produce luminescence, allowing after calibration the AFP level to be determined.

\section{Statistical analysis}

The results are expressed as mean \pm standard error of the mean value. Statistical analysis was performed using the Kruskal-Wallis non-parametric test in order to compare the differences between groups. Differences were considered to be significant when $p<0.05$. Each experiment was independently repeated 6 times for the mass transfer studies with vitamin B12 and 4 times for the biological studies.

\section{Results}

\section{Control and optimization of the alginate bead production process}

As explained previously, bead diameter was varied in order to investigate whether or not its reduction resulted in improved mass transfers through decreased diffusion distance and increased surface-to-volume ratio. Bead production first had to be optimized to maintain bead quality independent of bead diameter and to reduce waste fractions (Fig. 4A). Bead diameter was adjusted with the coaxial air-flow rate. Diameters ranging from 2000 to less than $600 \mu \mathrm{m}$ can be obtained. A very good correlation between these two parameters was obtained: the higher the air-flow rate, the lower the bead diameter (Fig. 4B). The number of satellites increased with an air-flow rate above $3700 \mathrm{ml} / \mathrm{min}$, regardless of the type and concentration of the alginate solution. The last two parameters had very little effect on bead diameter. Nevertheless, as shown in Fig. 4A, bead quality, bead shape and satellite fraction content were directly related to them. Beads shaped using 1\% alginate solution did not appear as spherical, as compared to those using $2 \%$ concentration. Many satellites were observed amongst bead samples generated from a $1 \%$ alginate concentration. Based on the 
Table 2. Mass transfer coefficient $\mathrm{K}$ in static conditions as a function of bead diameter and alginate type $(*$ : statistically different $(p<0.05)$ from condition LV $2.2 \% 600 \mu \mathrm{m}$, Kruskal-Wallis non parametric test, $\mathrm{N}=4$ ).

\begin{tabular}{|c|c|c|c|c|}
\hline Type of alginate & \multicolumn{2}{|c|}{ LV 2.2\% } & \multicolumn{2}{c|}{ MV 1.5\% } \\
\hline Bead diameter $(\mu \mathrm{m})$ & 600 & 1000 & 600 & 1000 \\
\hline $\mathrm{K}\left(10^{-7} \mathrm{~m} / \mathrm{s}\right)$ & $0.083 \pm 0.017$ & $0.164 \pm 0.040$ & $0.149 \pm 0.067$ & $0.235 \pm 0.075^{*}$ \\
\hline
\end{tabular}

Table 3. Mass transfer coefficient $\mathrm{K}$ in dynamic conditions as a function of bead diameter and alginate type (*: statistically different $(p<0.05)$ from condition MV $1.5 \% 600 \mu \mathrm{m}$, Kruskal-Wallis non parametric test, $\mathrm{N}=4$ ).

\begin{tabular}{|c|c|c|c|c|}
\hline & \multicolumn{2}{|c|}{ LV 2.2\% } & \multicolumn{2}{c|}{ MV 1.5\% } \\
\hline Type of alginate & 600 & 1000 & 600 & 1000 \\
\hline $\mathrm{K}\left(10^{-7} \mathrm{~m} / \mathrm{s}\right)$ & $3.718 \pm 1.132$ & $4.399 \pm 0.727$ & $2.563 \pm 0.119$ & $6.662 \pm 0.152 *$ \\
\hline
\end{tabular}

repeatability of the procedure, LV $2.2 \%$ and MV $1.5 \%$ appeared to be the most promising formulations for further use in FBBAL. They were appropriate for producing both $1000 \mu \mathrm{m}$ and $600 \mu \mathrm{m}$ beads. Fig. $4 \mathrm{C}$ shows bead diameter distribution around the target diameter for $1000 \mu \mathrm{m}$ and $600 \mu \mathrm{m}$ beads produced from LV 2.2\%. Although an increase in standard deviation was noticeable with decreasing bead diameter, the distribution around the target diameter for $600 \mu \mathrm{m}$ beads was still acceptable. As a result of the above-mentioned limitations, $600 \mu \mathrm{m}$ and $1000 \mu \mathrm{m}$ were the minimal and maximal diameters chosen to satisfy the quality requirements (bead integrity and sphericity, reduced satellite fraction).

\section{Mass transfer efficiency}

The decrease in vitamin B12 concentration over time in the tank illustrated its migration from the solution to the bead's internal accessible volume. In a previous study, we checked that vitamin B12 did not adsorb on alginate or bioreactor tubing (David et al., 2004). The transfer stopped as soon as both concentrations equilibrated, corresponding to a plateau. Mass transfers were hindered in the alginate beads because of scaffold porosity. Fig. 5 shows typical mass transfer curves obtained (A) in static conditions and (B) in dynamic conditions for $600 \mu \mathrm{m}-\mathrm{LV} 2.2 \%, 1000 \mu \mathrm{m}$ LV $2.2 \%$ and $1000 \mu \mathrm{m}-\mathrm{MV} 1.5 \%$ beads. The addition of perfusion led to a dramatic decrease in delay before equilibrium. In dynamic conditions, the equilibrium was effectively attained $10 \mathrm{~min}$ after the initiation of perfusion whereas $6 \mathrm{~h}$ were required in static conditions.

Using the mathematical model previously described, $\mathrm{K}$ could be successfully determined for the two selected types of alginate (LV 2.2\% and MV 1.5\%), for 600 and $1000 \mu \mathrm{m}$ beads respectively. Coefficient $\mathrm{K}$ directly reflects mass transfer efficiency (Tables 2 and 3).

In static conditions, vitamin B12 transfer seemed more hindered with LV 2.2\% alginate than with MV $1.5 \%$. The difference was statistically significant only between LV $2.2 \% 600 \mu \mathrm{m}$ and MV $1.5 \% 1000 \mu \mathrm{m}(p<0.05)$. This static trial thus helped in the analysis of pure diffusion transfer.
Bead porosity seemed to be tighter in the high density alginate. When convection was added (dynamic trials), this discrimination disappeared. In dynamic conditions, $\mathrm{K}$ coefficients were 50 and 20 to 30 times higher for 1000 and $600 \mu \mathrm{m}$ beads, respectively, than in static conditions. This trend was independent of the type of alginate. In all cases, mass transfers were much more efficient under dynamic (Table 3) than under static conditions (Table 2) because of the combination of diffusion and convection phenomena. This phenomenon has already been described by David et al. for a single type of bead (David et al., 2004a). A decrease in bead diameter unexpectedly led to a reduction in mass transfer coefficients. This trend was moderated when the available exchange surface area A was taken into account: $\mathrm{K} \times \mathrm{A}(\mathrm{KA})$ values were found to be identical for both diameters (Fig. 6). This decrease was balanced by the rise in surface area leading to identical KA values for both bead diameters. Larger KA was nevertheless expected for $600 \mu \mathrm{m}$ beads due to reduced diffusion length. The absence of difference could be due to the higher reticulation achieved for the $600 \mu \mathrm{m}$ beads which stayed as long as the $1000 \mu \mathrm{m}$ beads in the gelation bath.

\section{C3A cell culture and functionality}

Three types of beads were studied for the cell experiment in the FBBAL: $1000 \mu \mathrm{m}-\mathrm{MV} 1.5 \%, 1000 \mu \mathrm{m}-\mathrm{LV} 2.2 \%$ and $600 \mu \mathrm{m}-\mathrm{LV} 2.2 \%$. This set of parameters allowed the estimation of the effects on cells functions in the FBBAL of i) alginate type and ii) bead diameter, on the basis of paired analyses.

\section{Cell viability}

Fig 7 shows micrographs of the beads for cell viability before and after the fluidisation process. After the whole encapsulation process, mortality ranged from 15 to $25 \%$ leading to an initial number of cells of 37.5 to $42.5 \times 10^{6}$. The stress generated by air extrusion partially damaged the cells and specific attention should be paid to controlling the production process, more specifically in correctly 


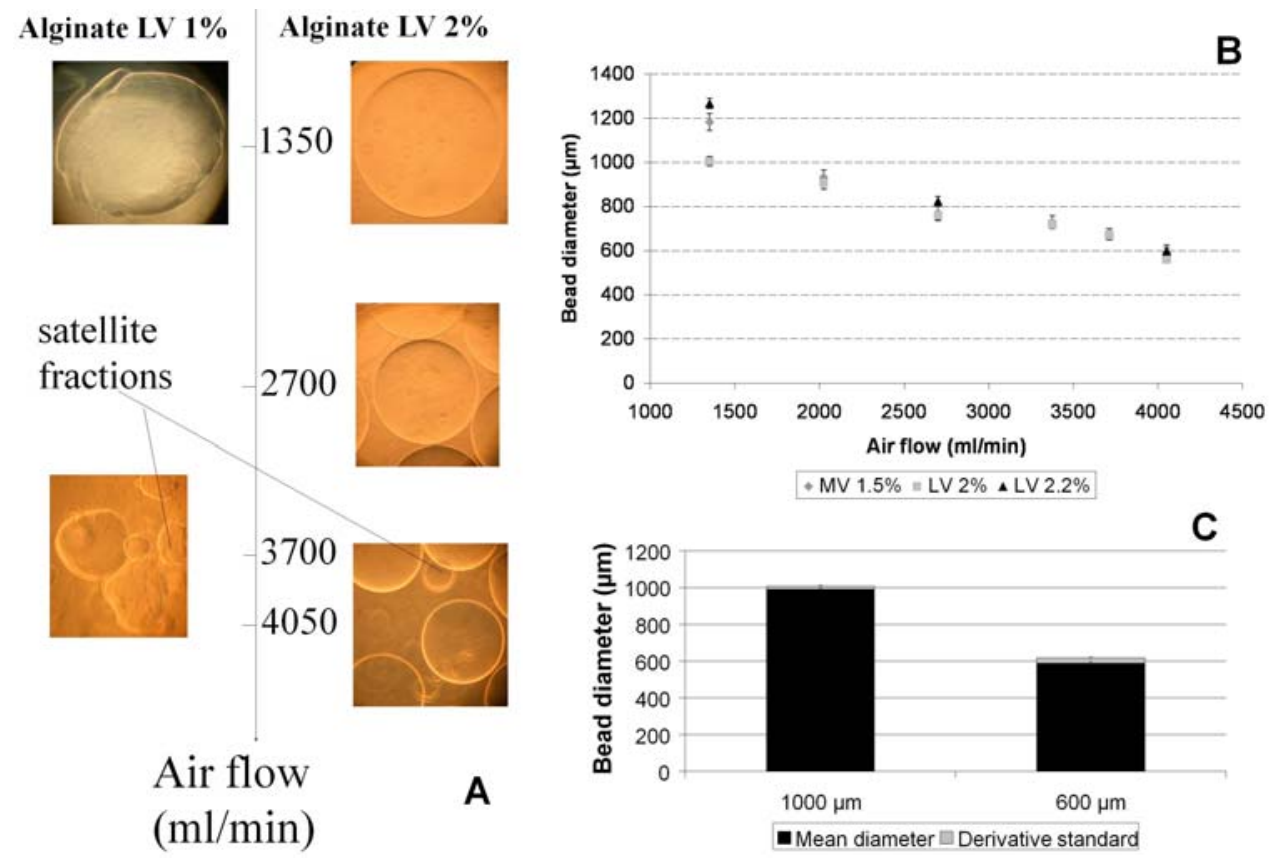

Fig. 4. Optimization of bead production. (A) Impact of alginate concentration and air-flow on bead sphericity and satellite fraction content. (B) Effect of air-flow on bead diameter. (C) Diameter dispersion as a function of bead size for $L V 2.2 \%$.
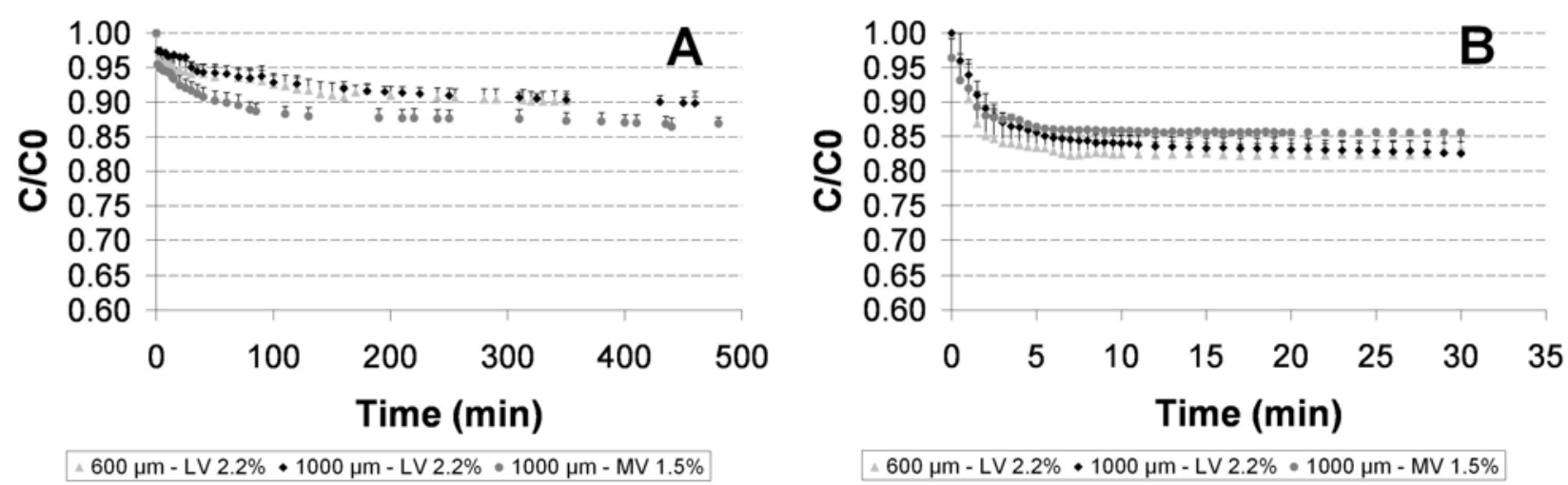

Fig. 5. Vitamin B12 absorption curves (A) in static and (B) in dynamic conditions for beads $600 \mu \mathrm{m}-\mathrm{LV} 2.2 \%, 1000$ $\mu \mathrm{m}-\mathrm{LV} 2.2 \%$ and $1000 \mu \mathrm{m}-\mathrm{MV} 1.5 \%$.
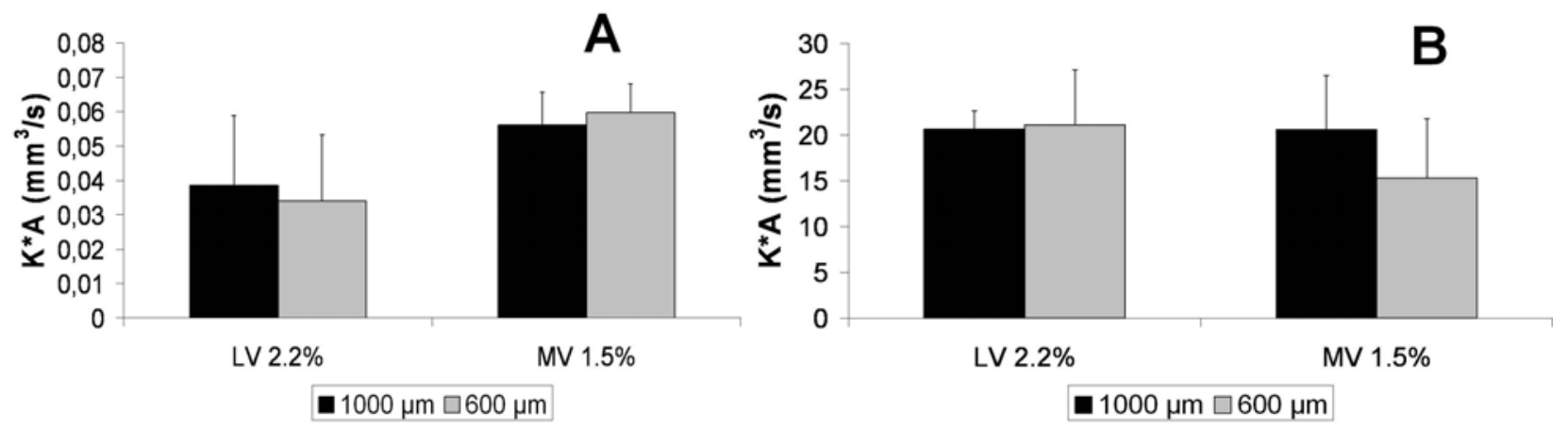

Fig. 6. Mass transfer coefficient $\mathrm{K}$ times available surface area $\mathrm{A}$ in static (A) and dynamic (B) conditions. 

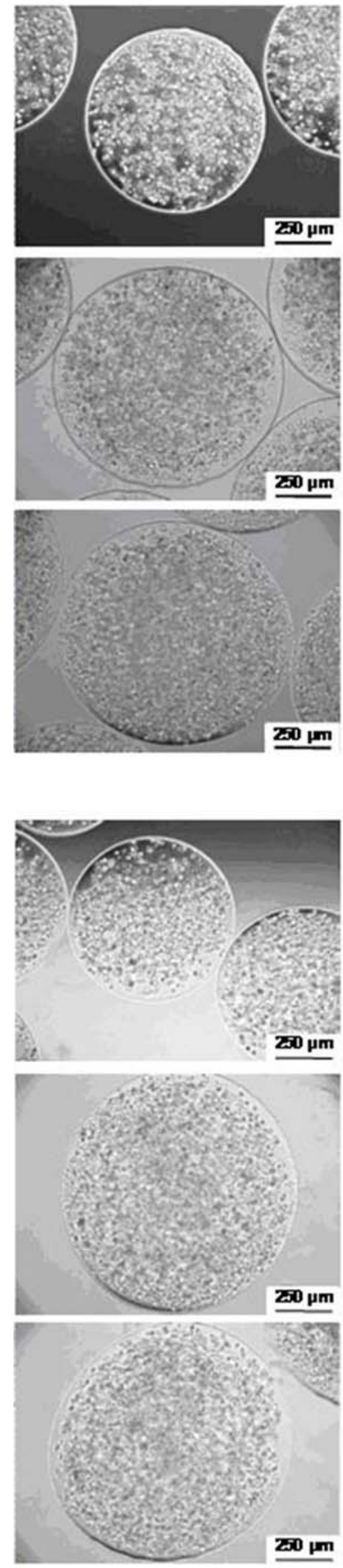
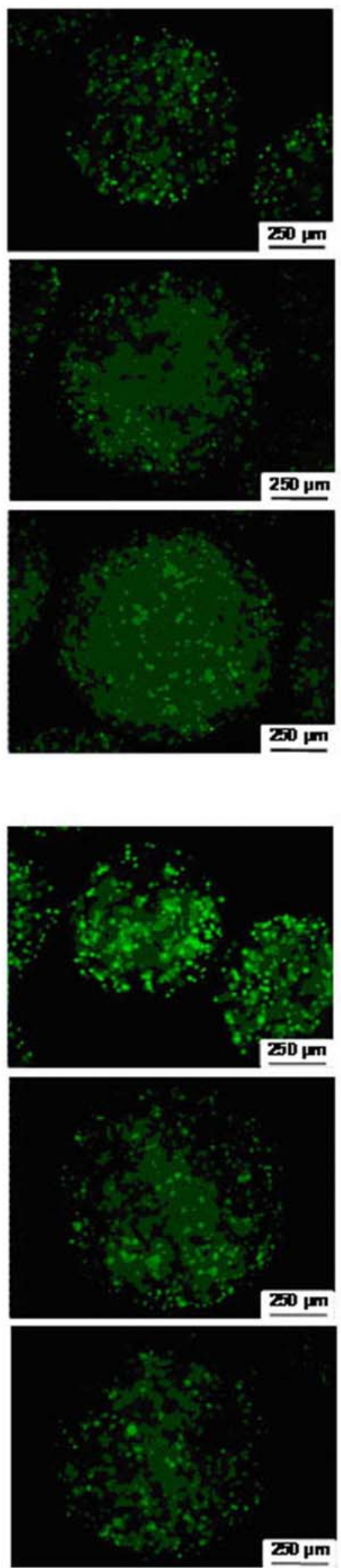
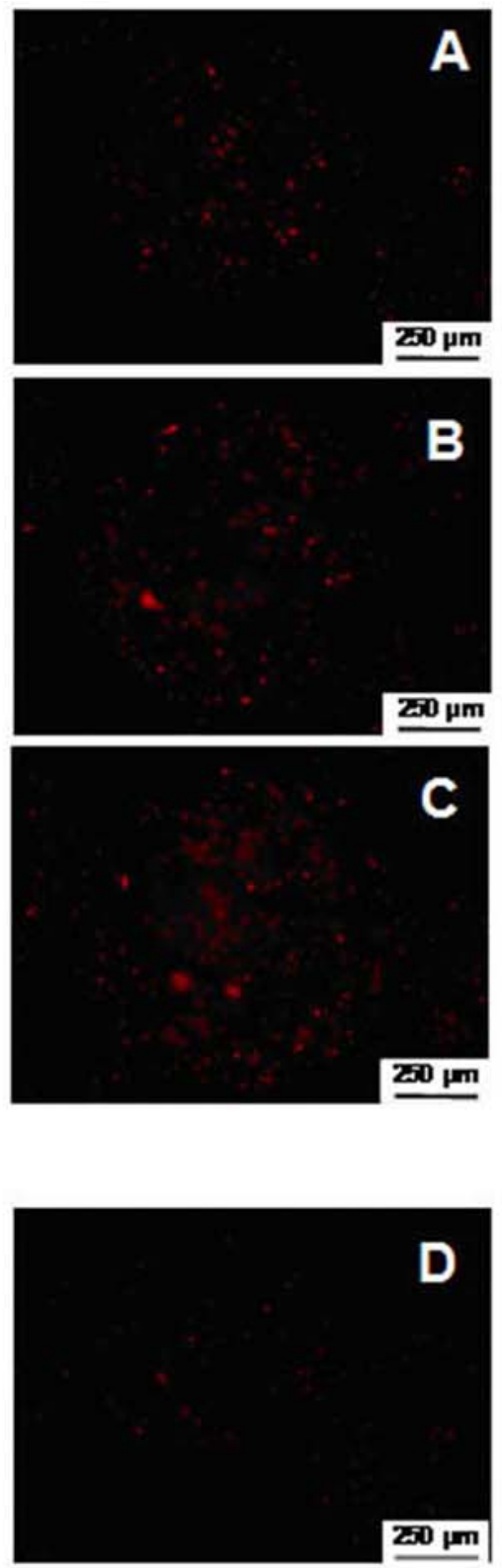

B

$\mathbf{2 0 0 \mu m}$
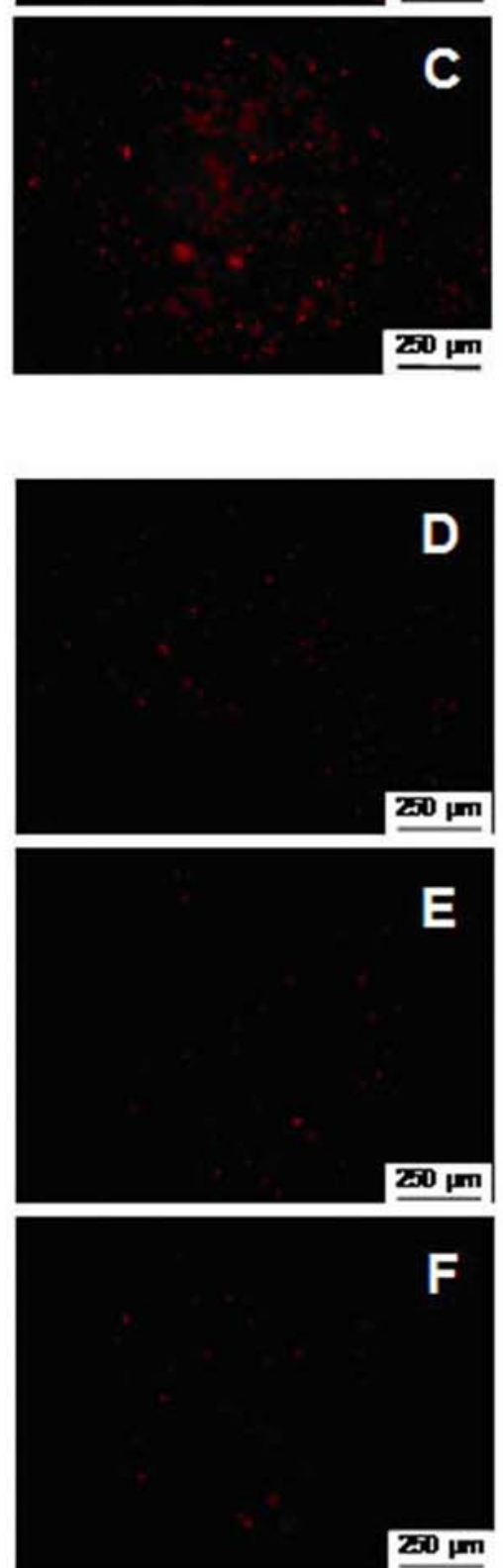

Fig. 7. Phase and fluorescence microscopy images of C3A-hosting beads before fluidisation (A) $600 \mu \mathrm{m}-\mathrm{LV}$ $2.2 \%$, (B) $1000 \mu \mathrm{m}-\mathrm{LV} 2.2 \%$, (C) $1000 \mu \mathrm{m}-$ MV 1.5\% and after fluidisation (D) $600 \mu \mathrm{m}-\mathrm{LV} 2.2 \%$. (E) $1000 \mu \mathrm{m}$ - LV 2.2\%, (F) $1000 \mu \mathrm{m}-\mathrm{MV} 1.5 \%$. Living cells are stained green with orange acridine whereas dead cells are stained red using propidium iodide. 

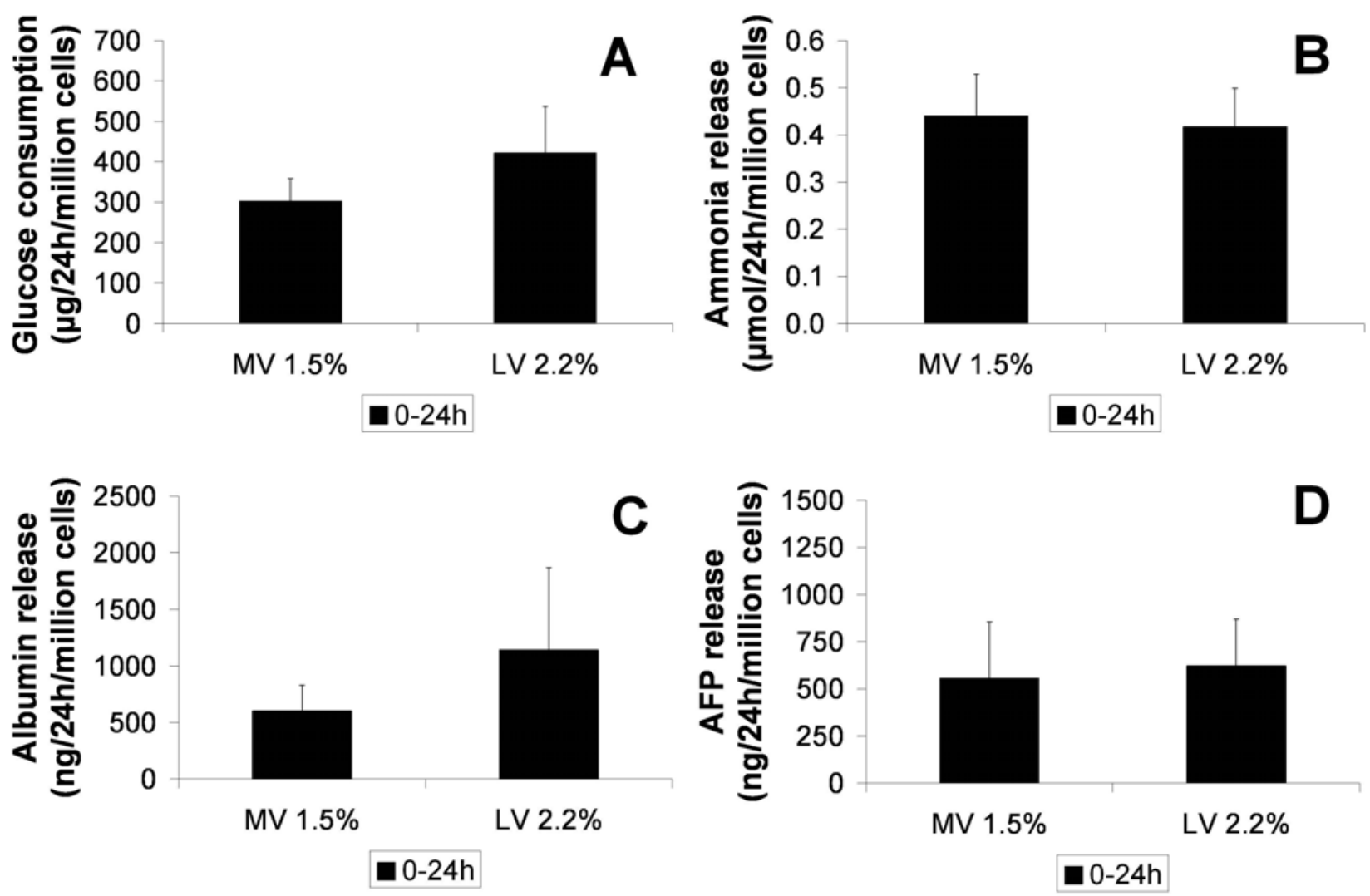

Fig. 8. Impact of alginate type on C3A cell metabolism and functionality. (A) Glucose consumption. (B) Ammonia, (C) albumin and (D) AFP releases. (no significant difference with Kruskal-Wallis non parametric test, $p<0.05, \mathrm{~N}=6$ ).
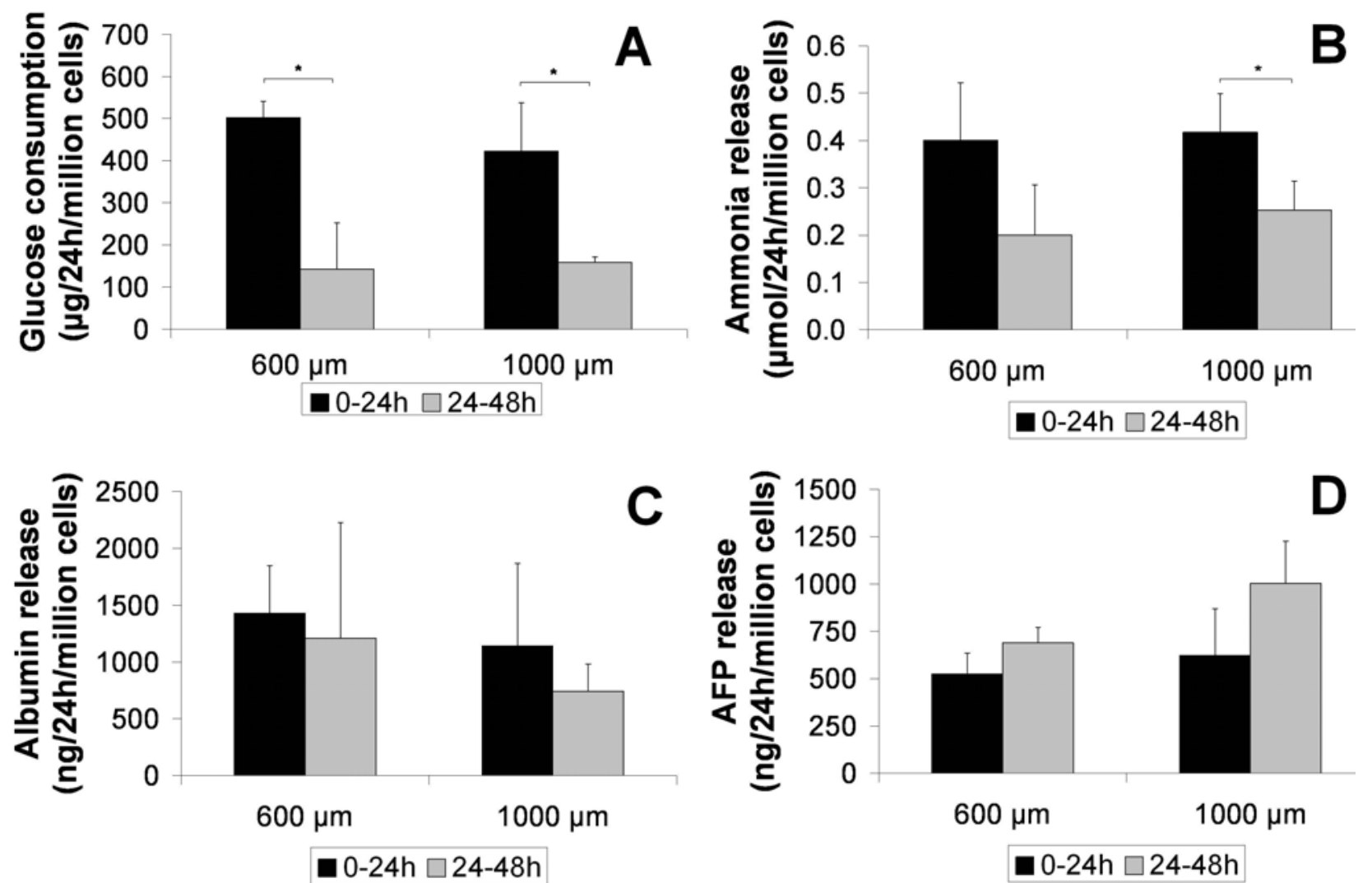

Fig. 9. Impact of bead diameter on C3A cell metabolism and functionality using LV $2.2 \%$. (A) Glucose consumption. (B) Ammonia, (C) albumin and (D) AFP releases. (* : $p<0.05$, Kruskal-Wallis non parametric test, $\mathrm{N}=6$ ). 
centring the needle within the nozzle. After the perfusion process, cell viabilities within beads were $85 \pm 2 \%, 83 \pm$ $7 \%, 94 \pm 1 \%$ for $1000 \mu \mathrm{m}-\mathrm{MV} 1.5 \%, 1000 \mu \mathrm{m}-\mathrm{LV} 2.2 \%$ and $600 \mu \mathrm{m}-\mathrm{LV} 2.2 \%$, respectively. For all types of alginate beads, cell mortality was higher before fluidisation compared to that observed at the $24 \mathrm{~h}$ and $48 \mathrm{~h}$ time points. The fluidisation process did not alter cell viability. Between the beginning and the end of the fluidisation process, neither cell proliferation nor re-organization was observed in any type of alginate bead.

\section{Effect of alginate type on cell functions in the FBBAL}

First, we investigated the effect of alginate type-MV 1.5\% and LV $2.2 \%$ - on cell metabolism in $1000 \mu \mathrm{m}$ beads (Fig. 8). Cell functions were indirectly assessed by four parameters - glucose, ammonia, albumin and AFP concentrations - which were monitored in the supernatant. The curves show the amount consumed or released within $24 \mathrm{~h}$ and in relation to the number of viable cells at the end of perfusion. Glucose consumption (Fig. 8A) was not statistically different for cells cultured in MV 1.5\% (302.80 $\pm 55.22 \mu \mathrm{g} / 24 \mathrm{~h} / 10^{6}$ cells $)$ or in LV $2.2 \%(422.21 \pm 114.91$ $\mu \mathrm{g} / 24 \mathrm{~h} / 10^{6}$ cells). It can thus be considered to be independent of culture conditions in the fluidised bed. In 2-D culture conditions, the same results were obtained (data not show). In the case of ammonia (Fig. 8B), the amounts released were similar in MV 1.5\% (0.44 $\pm 0.09 \mu \mathrm{mol} / 24$ $\mathrm{h} / 10^{6}$ cells $)$ or in LV $2.2 \%\left(0.42 \pm 0.08 \mu \mathrm{mol} / 24 \mathrm{~h} / 10^{6}\right.$ cells $)$. Due to its low molecular weight, ammonia solute could easily cross the alginate membrane and be found in the supernatant. Albumin release (Fig. 8C) was comparable for both types of bead $\left(602.42 \pm 226.72 \mathrm{ng} / 24 \mathrm{~h} / 10^{6}\right.$ cells for MV $1.5 \%$ and $1140.34 \pm 727.76 \mathrm{ng} / 24 \mathrm{~h} / 10^{6}$ cells for LV 2.2\%). The same trend was also observed for AFP (Fig. 8D) $\left(556.70 \pm 299.36 \mathrm{ng} / 24 \mathrm{~h} / 10^{6}\right.$ cells for MV $1.5 \%$ alginate beads and $622.02 \pm 246.15 \mathrm{ng} / 24 \mathrm{~h} / 10^{6}$ cells for LV 2.2\%). In summary, the results concerning glucose consumption, ammonia, albumin and AFP releases were not statistically different between either types of alginate. Alginate LV 2.2\% was therefore selected for the second part of the study as bead production using it was of better quality and did not require additional steps for the removal of potential satellite fractions.

\section{Effect of bead diameter on cell functions in the FBBAL}

We then studied the impact of bead diameter -600 and $1000 \mu \mathrm{m}$ - on cell metabolism in alginate LV 2.2\% (Fig. 9). Although classical use of FBBAL in clinics should not be for any longer than one day using the same batch of cells, the experiments were prolonged to $48 \mathrm{~h}$ perfusion to potentially highlight any differences related to bead diameter. Between 0-24 h of fluidisation, glucose consumption (Fig. 9A) was not significantly different for cells cultured in $600 \mu \mathrm{m}$ beads $(501.88 \pm 38.68 \mu \mathrm{g} / 24 \mathrm{~h} /$ $10^{6}$ cells $)$ or in $1000 \mu \mathrm{m}$ beads $(422.21 \pm 114.91 \mu \mathrm{g} / 24 \mathrm{~h} /$ $10^{6}$ cells). Between 24-48 h of perfusion, glucose consumption significantly decreased in the same proportion for both types of bead. It should be noted that glucose concentration was very low in the supernatant after
$24 \mathrm{~h}$ of perfusion $(2.77 \pm 0.40 \mathrm{mmol} / \mathrm{l}$ for $600 \mu \mathrm{m}$ beads and $2.92 \pm 0.51 \mathrm{mmol} / 1$ for $1000 \mu \mathrm{m}$ beads). The release of ammonia (Fig. 9B) between $0-24 \mathrm{~h}$ of fluidisation was not statistically different for $600 \mu \mathrm{m}$ beads $(0.40 \pm 0.12$ $\mu \mathrm{mol} / 24 \mathrm{~h} / 10^{6}$ cells $)$ and $1000 \mu \mathrm{m}$ beads $(0.42 \pm 0.08 \mu \mathrm{mol} /$ $24 \mathrm{~h} / 10^{6}$ cells). Between $24-48 \mathrm{~h}$ of perfusion, ammonia release decreased for both types of bead. For high molecular weight solutes, the results did not follow the same trend. Figs 9C and 9D revealed that albumin and AFP released from the beads into the medium was still occurring after $48 \mathrm{~h}$. This could be explained by a delayed release of these proteins - because of the porous structure of the alginate beads - although there might already have been an impact on synthesis. It was all the more obvious for AFP: a higher amount was liberated on day 2 while synthesis was expected to be lower than during the first $24 \mathrm{~h}$ period (Fig. 9D).

\section{Discussion}

The extrusion method with co-axial air flow can be successfully adjusted to produce beads of 600 and 1000 $\mu \mathrm{m}$ in diameter from different types of alginate - low and medium viscosity - ensuring their integrity and their sphericity, and above all without the presence of satellite fractions.

The molecular weight of the solutes has a direct impact on their ability to migrate through the porous structure of the gel. Low to middle molecular weight solutes, such as glucose, ammonia or vitamin B12, can easily cross the alginate membrane, regardless of the type of alginate (LV or MV). Their sieving coefficient is almost 1. For larger molecules such as albumin and AFP, transfers appears to be hindered by the porous structure, but still take place, indicating that the bead cut off is greater than the size of albumin $(66,000 \mathrm{Da})$. Previous studies have already shown that the bead structure was impermeable to immunoglobulins (Fremond et al., 1996; Clement et al., 1998; Figliuzzi et al., 2006). These results therefore completely meet the requirements for future BAL applications.

According to Zmora et al. (2002), pore architecture in 3-D alginate scaffolds plays a critical role in hepatocyte organization inside functioning tissue. Consequently, hepatocyte microencapsulation was investigated with two types of alginate (LV or MV) and with different diameters (final choices: 600 or $1000 \mu \mathrm{m}$ ), taking into consideration the fact that alginate structure may have an environmental impact on cell viability, morphology and metabolism. This impact could be related to the density of the network (correlated with the porosity of the structure) surrounding the cells. Porosity changes could directly affect the cell morphology, depending on the shape of the "chambers" offered to them. In addition, as in any porous material, the effective diffusivity of substances is dramatically reduced as compared to that observed in free solution: the lower the porosity, the more hindered the mass transfers. This could lead to reduced viability if nutrient supply is no longer achieved, or to retention of substances within the beads, leading to apparently reduced biological functions, 
for the purpose of supply to the liver. Under the conditions of the study, these effects were not observed. Beads with a diameter of $1000 \mu \mathrm{m}$ produced from LV 2.2\% had many advantages: good quality, high resistance, easy production. For future BAL applications, bead diameter $1000 \mu \mathrm{m}$ and alginate type LV $2.2 \%$ are therefore recommended in comparison with LV $2.2 \%$ beads with a diameter of 600 $\mu \mathrm{m}$ and MV $1.5 \%$ beads with a diameter of $1000 \mu \mathrm{m}$.

In the present investigations, cells were not found to proliferate or to re-organize inside any type of alginate beads during the $48 \mathrm{~h}$ experiment. Bazou et al. (2008), using alginate gelified under much milder conditions, did not observe any proliferation of spheroids cultivated in the matrix from day 0 to day 3. The increase of growth rate was noticeable from day 3 to day 10 , in static conditions. These results were similar to those of Khalil et al. (2001), who showed low cell number variation up to 5 days after the encapsulation process in $400 \mu \mathrm{m}$ bead diameter made of lower alginate concentration $(1 \%)$. The same team showed that HepG2 cells proliferated during the period of 10-20 days after encapsulation (Coward et al., 2005). In another study, we qualitatively followed C3A proliferation inside alginate beads under static conditions over a longer period of time (after 7 and 14 days of culture) (Kinasiewicz et al., 2008). Channel-like structures and spherical aggregates were observed in the beads using both medium and low viscosity alginate. Very recently, Wang et al. (2009) showed that the choice of alginate concentration allowed control over the matrix porosity/ flexibility to permit the proliferation and growth of encapsulated cells.

These different results suggest that cell proliferation and re-organization can be obtained, provided that alginate concentration is not too high and reticulation is limited, offering the cells enough space to grow, and that a sufficient delay is allowed.

Dynamic culture in a fluidised bed bioreactor appears to be a valuable technique for maintaining cell functions for at least $48 \mathrm{~h}$, if sufficient quantities of glucose are provided. The low glucose concentration in the supernatant between 24 and $48 \mathrm{~h}$ observed for both types of beads (600 $\mu \mathrm{m}$ and $1000 \mu \mathrm{m}$ diameters) could lead to an alteration in cell metabolism. A comparative study of the effects of medium components on hepatocyte functionality in suspension culture highlighted a decrease in ATP/ADP ratio in glucose-free medium (Elaut et al., 2005). Mukwena showed that the absence of glucose inhibited hepatocyte proliferation without any observable effect on cell viability for $96 \mathrm{~h}$ culture (Mukwena and Al-Rubeai, 2004). Our results confirm these findings, with culture conditions in beads preserving cell viability higher than $83 \%$ after 24 or $48 \mathrm{~h}$ of fluidisation.

For future BAL applications, two different approaches to cell encapsulation could be considered: 1) start with a low number of cells and let them grow inside an appropriate culture device (suitable if a highly proliferative cell line is employed); 2) prepare a larger amount of cells in advance, and directly encapsulate the number required (recommended when using primary cells).

Finally, our first hypothesis that diameter reduction would result in accelerated transfer was not confirmed, for any type of solute in either empty or loaded beads. Martinsen et al. showed that two factors have an impact on the volume reduction of the beads after the gelation process: 1) the concentration in $\mathrm{CaCl}_{2}$ (the higher the concentration, the more significant the volume reduction); 2 ) the gelation time (the percentage of volume reduction of the alginate beads increased with incubation time) (Martinsen et al., 1989). In our case, the $\mathrm{CaCl}_{2}$ concentration as well as the gelation time was set for the $1000 \mu \mathrm{m}$ beads used in our previous studies. Under these conditions, the $600 \mu \mathrm{m}$ alginate bead matrix may have been too compact and the transfers minimised.

In future studies, these two parameters could be adjusted, keeping in mind that the reduction of $\mathrm{CaCl}_{2}$ concentration or gelation time could lead to higher bead porosity and better permeability, as expected, but also to a lack of mechanical stability or to the absence of core gelation. Biochemical modifications might also be considered to improve the interaction between the cells and the alginate biomaterial (Yang et al., 2002). Of the options, the RGD (arginine-glycine-aspartic acid) amino acid sequence could be grafted onto the material. RGD is a key cell adhesion peptide found in many extracellular matrix proteins with which cell adhesion receptors interact. This interaction improves cell adhesion and modulates specific metabolic responses. With an RGD amino acid sequence immobilized on polyethersulfone membranes, De Bartolo et al. (2005) show the benefits in terms of the adhesion, proliferation and albumin synthesis of primary human hepatocytes.

\section{Conclusions}

In our present work, we investigated several combinations of alginate type and bead diameter to obtain the best cell functions after encapsulation. Considering production procedure and assessed cell functions, we conclude that beads with a diameter of $1000 \mu \mathrm{m}$ offer a reliable entrapment process for hepatocytes that are to be used in a fluidised bed bioartificial liver.

\section{Acknowledgements}

The authors would like to thank Dr. Delavenne for his kind assistance, as well as Dr. Sanchez (Compiègne Hospital) whose precious help in analyzing the AFP marker was greatly appreciated. They would also like to thank P. Georgin, M. Gouet and G. Le Pape for developing the statistical analysis tools accessible on AnaStats.fr. Thanks are also given to Kirsty Snaith for reading and correcting the English.

\section{References}

Bajpai SK, Sharma S (2004) Investigation of swelling/ degradation behaviour of alginate beads crosslinked with $\mathrm{Ca}^{2+}$ and $\mathrm{Ba}^{2+}$ ions. Reactive and Functional Polymers 59: 129-140. 
Bazou D, Coakley WT, Hayes AJ, Jackson SK (2008) Long-term viability and proliferation of alginateencapsulated 3-D HepG2 aggregates formed in an ultrasound trap. Tox In Vitro 22: 1321-1331.

Berthiaume F, Moghe PV, Toner M, Yarmush ML (1996) Effect of extracellular matrix topology on cell structure, function, and physiological responsiveness: hepatocytes cultured in a sandwich configuration. FASEB J 10: 1471-1484.

Canaple L, Nurdin N, Angelova N, Saugy D, Hunkeler D, Desvergne B (2001) Maintenance of primary murine hepatocyte functions in multi component polymer capsules - in vitro cryopreservation studies. J Hepatol 34: 11-18.

Carpentier B, Gautier A, Legallais C (2009) Artificial and bioartificial liver devices: present and future. Gut 58: 1690-1702.

Chang TM (2005) Therapeutic applications of polymeric artificial cells. Nat Rev Drug Discov 4: 221 235.

Clement B, Desille M, Fremond B, Campion JP, Guguen-Guillouzo C, Bourel M (1998) Hepatocytes en therapie cellulaire [Hepatocytes in cell therapy]. Transfus Clin Biol 5: 80-87.

Coward SM, Selden C, Mantalaris A, Hodgson HJ (2005) Proliferation rates of HepG2 cells encapsulated in alginate are increased in a microgravity environment compared with static cultures. Artif Organs 29: 152-158.

David B, Barbe L, Barthes-Biesel D, Legallais C (2006) Mechanical properties of alginate beads hosting hepatocytes in a fluidized bed bioreactor. Int J Artif Organs 29: 756-763.

David B, Doré E, Jaffrin MY, Legallais C (2004) Mass transfer in a fluidized bed bioreactor using alginate beads for a future bioartificial liver. Int J Artif Organs 27: 284293.

David B, Dufresne M, Nagel MD, Legallais C (2004) In vitro assessment of encapsulated $\mathrm{C} 3 \mathrm{~A}$ hepatocytes functions in a fluidised bed bioreactor. Biotechnol Prog 20: 1204-1212.

De Bartolo L, Morelli S, Lopez LC, Giorno L, Campana C, Salerno S, Rende M, Favia P, Detomaso L, Gristina R, Agostino R, Drioli E (2005) Biotransformation and liverspecific functions of human hepatocytes in culture on RGD-immobilized plasma-processed membranes. Biomaterials 26: 4432-4441.

De Vos P, Faas MM, Strand B, Calafiore R (2006) Alginate-based microcapsules for immunoisolation of pancreatic islets. Biomaterials 27: 5603-5617.

Dore E, Legallais C (1999) A new concept of bioartificial liver based on a fluidized bed bioreactor. Ther Apher 3: 264-267.

Elaut G, Vanhaecke T, Heyden YV, Rogiers V (2005) Spontaneous apoptosis, necrosis, energy status, glutathione levels and biotransformation capacities of isolated rat hepatocytes in suspension: effect of the incubation medium. Biochem Pharmacol 69: 1829-1838.

Figliuzzi M, Plati T, Cornolti R, Adobati F, Fagiani A, Rossi L, Remuzzi G, Remuzzi A (2006) Biocompatibility and function of microencapsulated pancreatic islets. Acta Biomater 2: 221-227.
Fremond B, Joly A, Desille M, Desjardins JF, Campion JP, Clement B (1996) Cell-based therapy of acute liver failure: the extracorporeal bioartificial liver. Cell Biol Toxicol 12: 325-329.

Gao Y, Jiang HC, Xu J, Pan SH, Li YD (2005) Microencapsulating hepatocytes. Transplant Proc 37: 4589-4593.

Garbayo I, Leon R, Vilchez C (2002) Diffusion characteristics of nitrate and glycerol in alginate. Colloids Surf B 25: 1-9.

Haque T, Chen H, Ouyang W, Martoni C, Lawuyi B, Urbanska A, Prakash S (2005) Investigation of a new microcapsule membrane combining alginate, chitosan, polyethylene glycol, poly-L-lysine for cell transplantation applications. Int J Artif Organs 28: 631-637.

Jiankang H, Dichen L, Yaxiong L, Bo Y, Hanxiang Z, Qin L, Bingheng L, Yi L (2009) Preparation of chitosangelatin hybrid scaffolds with well-organized microstructures for hepatic tissue engineering. Acta Biomater 5: 453-461.

Khalil M, Shariat-Panahi A, Tootle R, Ryder T, McCloskey P, Roberts E, Hodgson H, Selden C (2001) Human hepatocyte cell lines proliferating as cohesive spheroid colonies in alginate markedly upregulate both synthetic and detoxificatory liver function. J Hepatol 34: 68-77.

Kinasiewicz A, Gautier A, Lewinska D, Bukowski J, Legallais C, Werynski A (2007) Culture of C3A cells in alginate beads for fluidized bed bioartificial liver. Transplant Proc 39: 2911-2913.

Kinasiewicz A, Gautier A, Lewinska D, Smietanka A, Legallais C, Werynski A (2008) Three-dimensional growth of human hepatoma $\mathrm{C} 3 \mathrm{~A}$ cells within alginate beads for fluidized bioartificial liver. Int J Artif Organs 31: 340-347.

Legallais C, Dore E, Paullier P (2000) Design of a fluidized bed bioartificial liver. Artif Organs 24: 519-525.

Legallais C, David B, Dore E (2001) Bioartificial livers (BAL): currrent technological aspects and future developments. J Membr Sci 181: 81-95.

Legallais C, Gautier A, Dufresne M, Carpentier B, Baudoin R (2008) The place of adsorption and biochromatography in extracorporeal liver support systems. J Chromatogr B 861: 171-176.

Lewinska D, Rosinski S, Hunkeler D, Poncelet D, Werynski A (2002) Mass transfer coefficient in characterization of gel beads and microcapsules. J Membr Sci 209: 533-540.

Martinsen A, Skjak-Braek G, Smidsrod O (1989) Alginate as immobilization material: I. Correlation between chemical and physical properties of alginate gel beads. Biotechnol Bioeng 33: 79-89.

Mukwena NT, Al-Rubeai M (2004) Apoptosis and its suppression in hepatocytes culture. Cytotechnology 46: 79-95.

Orive G, Hernandez RM, Rodriguez Gascon A, Calafiore R, Chang TM, De Vos P, Hortelano G, Hunkeler D, Lack I, Pedraz JL (2004) History, challenges and perspectives of cell microencapsulation. Trends Biotechnol 22: 87-92. 
Orive G, Tam SK, Pedraz JL, Halle JP (2006) Biocompatibility of alginate-poly-1-lysine microcapsules for cell therapy. Biomaterials 27: 3691-3700.

Paul A, Ge Y, Prakash S, Shum-Tim D (2009) Microencapsulated stem cells for tissue repairing: implications in cell-based myocardial therapy. Regen Med 4: 733-745.

Selden C, Shariat A, McCloskey P, Ryder T, Roberts E, Hodgson H (1999) Three-dimensional in vitro cell culture leads to a marked upregulation of cell function in human hepatocyte cell lines-an important tool for the development of a bioartificial liver machine. Ann NY Acad Sci 875: 353-863.

Seo SJ, Kim IY, Choi YJ, Akaike T, Cho CS (2006) Enhanced liver functions of hepatocytes cocultured with NIH $3 \mathrm{~T} 3$ in the alginate/galactosylated chitosan scaffold. Biomaterials 27: 1487-1495.

Tsai WB, Lin JH (2009) Modulation of morphology and functions of human hepatobastoma cells by nanogrooved substrata. Acta Biomater 5: 1442-1454.

Tuschl G, Hrach J, Walter Y, Hewitt PG, Mueller SO (2009) Serum-free collagen sandwich cultures of adult rat hepatocytes maintain liver-like properties long term: a valuable model for in vitro toxicity and drug-drug interaction studies. Chem Biol Interact 181: 124-137.

Ueyama Y, Ishikawa K, Mano T, Koyama T, Nagatsuka H, Suzuki K, Ryoke K (2002) Usefulness as guided bone regeneration membrane of the alginate membrane. Biomaterials 23: 2027-2033.
Vollmar B, Menger MD (2009) The hepatic microcirculation: mechanistic contributions and therapeutic targets in liver injury and repair. Physiol Rev 89: 1269-339.

Wang N, Adams G, Buttery L, Falcone FH, Stolnik S (2009) Alginate encapsulation technology supports embryonic stem cells differentiation into insulin-producing cells. J Biotechnol 144: 304-312.

Wikstrom J, Elomaa M, Syvajarvi H, Kuokkanen J, Yliperttula M, Honkakoski P, Urtti A (2008) Alginatebased microencapsulation of retinal pigment epithelial cell line for cell therapy. Biomaterials 29: 869-876.

Yang J, Goto M, Ise H, Cho CS, Akaike T (2002) Galactosylated alginate as a scaffold for hepatocytes entrapment. Biomaterials 23: 471-479.

Zimmermann H, Wehlisch F, Baier C, Westhoff M, Reuss R, Zimmermann D, Behringer M, Ehrhart F, KatsenGloba A, Giese C, Marx U, Sukhorukov VL, Vasquez JA, Jakob P, Shirley SG, Zimmermann U (2007) Physical and biological properties of barium cross-linked alginate membranes. Biomaterials 28: 1327-1345.

Zmora S, Glicklis R, Cohen S (2002) Tailoring the pore architecture in 3-D alginate scaffolds by controlling the freezing regime during fabrication. Biomaterials 23: 40874094.

Editor's Note: All questions/comments from the reviewers of this paper were answered by text changes. Hence, there is no "Discussion with Reviewers" section. 